Каламан О.Б.

кандидат економічних наук, доцент кафедра менеджменту і логістики

E-mail: buxgalter11@ukr.net

Молчановська А.C.

магістрант

кафедра безпеки, експертизи і товарознавства

Одеська національна академія харчових технологій

вул. Канатна, 112, м. Одеса, Україна, 65039

E-mail: anastasiia_molchanovska@mail.ru

\title{
ТЕНДЕНЦІЇ РОЗВИТКУ СВІТОВОГО ТА УКРАЇНСЬКОГО РИНКУ ПРОДУКЦІЇ ВИНОРОБСТВА В СУЧАСНИХ УМОВАХ
}

Розглянуті сучасні проблеми та тенденції світового та українського ринків продукції виноробства. Показані зміни площ виноградних насаджень у світі. Виділені та проаналізовані нові лідери в світовій виноробній галузі. Зображений стан розвитку виноградарства в Україні та описані його проблеми в сучасних нестабільних умовах. Вказані гострі проблеми та загрози виноробної галузі України. Запропоновані шляхи для поліпшення та розвитку виноробної галузі в Україні.

Ключові слова: виноградарство, виноробство, галузь, ринок, виробництво, розвиток.

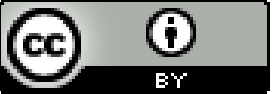

This work is licensed under a Creative Commons Attribution 4.0 International License http://creativecommons.org/licenses/by/4.0/
Постановка проблеми та її зв'язок з вважливими науковими та практичними задачами. В період інтенсивного розвитку сучасного ринку виноробної продукції, де площі плодоносних виноградників зменшуються швидкими темпами, споживання вина збільшується, а конкуренція зі сторони нових винних держав зростає - особливого значення набувають сучасні тенденції розвитку світового та вітчизняного ринку продукції виноградарства та виноробства.

Аналіз останніх публікацій по проблемі. Проблеми розвитку ринку продукції виноробства та виноградарства в нестабільних умовах сьогодення знайшли відображення у працях наступних науковців - В. А. Виноградова, А. М. Авідзба, В.А. Загоруйко, Н.П. Петруні, Г. Г. Валуйко, І. Г. Матчиної, О. М. Гаркуші, А. М. Бузні та ін.

Формулювання цілей дослідження. Основною метою дослідження є детальний та систематичний розгляд актуальних проблем та сучасних тенденцій розвитку світового та українського ринку продукції виноградарства. Також метою було виявлення гострих питань у виноробній галузі України та виокремлення шляхів їх оптимального вирішення.

Виклад основних результатів та їх обгрунтування. Виноградарство розвинене у багатьох країнах світу. Основними лідерами світового виробництва виноробної продукції прийнято вважати Францію, Італію, Іспанію. Але у зв'язку з виходом на світовий ринок нових винних держав, таких як Китай, Туреччина, Південна Африка, значно складніше утримувати лідерські показники виробництва вина та винороб- ної продукції на світовому ринку, адже конкуренція з кожним роком зростає.

На нових територіях відбувається поступове збільшення площ виноградників, у той час, як європейські країни повинні скорочувати площі. Так на сьогодні п'ятірку лідерів за об'ємом площі виноградників, які складають 50 \% від світового об'єму площі, займають Іспанія (1023 млн. га), Франція (793 млн. га), Італія (752 млн. га), Китай (680 млн. га), та Туреччина (504 млн. га) [1].

Загальна площа світових виноградників знижується за рахунок зменшення площі європейських країн, і хоча, загальна доля була компенсована збільшенням площ в інших частинах світу, доля Європи знизилась 3 62,5\% до 55\% світових виноградників. Не зважаючи на це, доля інших регіонів зростає, зокрема в Азії, де зараз доля світових виноградників займає 24\%, Також в Америці з 12\% відбулось збільшення до $14 \%$, в Африці з 4,3\% до 5\%[1].

Китай виробляє 15\% виноградарської продукції від світового виробництва, Італія - 10\% та США - 10\%. Відбулось значне збільшення виробництва в Китаї, Індії та Чилі. І хоча ці країни не набули ще статусу світових лідерів - їх тенденції вказують на перспективний розвиток в галузі виноградарства та виноробства. Вже сьогодні Азія є крупним виробником вина, продуктивність якого складає 62\% від світового виробництва. Статистика виробництва вина по країнах за даними OIV (International Organisation of Vine and Wine) наведена в табл.1. 
Таблиця 1

Світове виробництво вина у 2010-2014 роках, млн. гл. [4]

\begin{tabular}{|c|c|c|c|c|c|c|c|}
\hline Країна & $\mathbf{2 0 1 0}$ & $\mathbf{2 0 1 1}$ & $\mathbf{2 0 1 2}$ & $\mathbf{2 0 1 3}$ & $\mathbf{2 0 1 4}$ & $\begin{array}{c}\mathbf{1 4 / 1 3} \text { абсолютне } \\
\text { відхилення, гл. }\end{array}$ & $\begin{array}{c}\mathbf{1 4 / 1 3} \text { відносне } \\
\text { відилення, \% }\end{array}$ \\
\hline Франція & 44381 & 50757 & 41548 & 42004 & 46698 & +4694 & +11 \\
\hline Італія & 48525 & 42772 & 45616 & 54029 & 44739 & -9290 & -17 \\
\hline Іспанія & 35353 & 33397 & 31123 & 45650 & 41620 & -4030 & -9 \\
\hline США & 20887 & 19140 & 21650 & 23590 & 22300 & -1290 & -5 \\
\hline Аргентина & 16250 & 15473 & 11778 & 14984 & 15197 & +213 & +1 \\
\hline Австралія & 11420 & 11180 & 12260 & 12500 & 12000 & -500 & -4 \\
\hline П. Африка & 9327 & 9725 & 10569 & 10982 & 11316 & +334 & +3 \\
\hline Китай & 13000 & 13200 & 13511 & 11780 & 11178 & -602 & -5 \\
\hline Чілі & 8844 & 10464 & 12554 & 12820 & 10500 & -2320 & -18 \\
\hline Германія & 6906 & 9132 & 9012 & 8409 & 9334 & +925 & +11 \\
\hline Португалія & 7148 & 5622 & 6308 & 6327 & 6195 & -132 & -2 \\
\hline Румунія & 3287 & 4058 & 3311 & 5113 & 4093 & -1020 & -20 \\
\hline Н. Зеландія & 1900 & 2350 & 1940 & 2484 & 3204 & +720 & +29 \\
\hline Греція & 2950 & 2750 & 3115 & 3343 & 2900 & -443 & -13 \\
\hline Угорщина & 1762 & 2750 & 1818 & 2666 & 2734 & +68 & +3 \\
\hline Усього & 264425 & 267279 & 257889 & 291902 & 278800 & -13102 & -4 \\
\hline
\end{tabular}

А виноградарство України у зв'язку з останніми політичними подіями зазначило значні втрати площ виноградників. Після анексії Криму загальна площа українських виноградників зменшилась 3 75,1 тис. га до 48, 7 тис. га у 2014 році. Динаміка розвитку виноградарства в Україні наведена на рис. 1.

У сільських господарствах населення урожайність винограду завжди була високою, і на зараз зросла. За рахунок вдалого урожаю винограду, загальний об'єм виробництва після ситуації з Кримом, значно зменшився, ніж зміни та зменшення виноградників у плодоносному віці. Натомість у сільських господарствах населення, завдяки урожайності, в той час, як площа виноградників зменшується на 3,1\%, валовий збір винограду навпаки збільшується на 1,8\%. Усі підприємства сільського господарства, які вирощують виноград, в більшій мірі зосереджені на великих господарствах, ті, в свою чергу налічують більше 500 га виноградників. Так у 2013 р. 32 таких господарства виробляли приблизно 60\% винограду, не беручи до уваги Крим, а на сьогодні в них відбулись не суттєві зміни (виробництво винограду складає 57,1\%) [5].

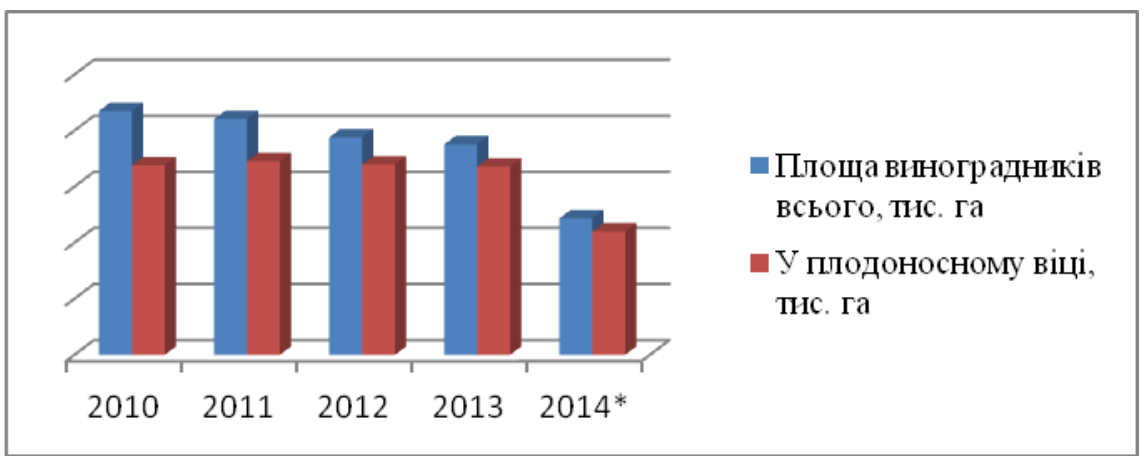

Рис.1. Динаміка розвитку виноградарства в Україні в період 32010 - 2014 рр. [4] 2014* - без врахування території АР Крим

Найкращі показники мають великі господарства, загальна середня площа у яких складає 797 га виноградників. Так у 2013p. урожайність у них склала 101 ц/га проти 86 ц/га по всіх сільськогосподарських підприємствах, таким чином прибуток у розрахунку склав на 1 га виноградників - 14,7 тис. грн. (8,8 тис. грн.), а рівень рентабельності виробництва винограду сягав $136 \%(80 \%)$ [2].

Нажаль виноградарство займає невелику частку при виробництві валової продукції сільського господарства України - у 2014 р. частка виноградарс- тва складала лише $0,3 \%$, а у продукції рослинництва 0,55\%. Велику значимість тут відіграє зональне розташування та концентрація виробництва винограду. Наприклад, в Одеській області така частка складає 5,4 $\%$ та $6,6 \%$, у Миколаївській області - 1,3 і 1,7\%, Херсонській - 1,2 і 1,6\% відповідно. Натомість, частка виноградарства сільськогосподарських підприємств у прибутках є значно вищою - так по Україні вона складає $0,7 \%$, в Одеській області - 3,3\%, у Миколаївській області - 5,3\%, у Херсонській - 5,4\%, тощо[3]. 
У 2012 та 2013 рр. біля 3/4 українського винограду (відповідно 71,2 і 73,9\%) були використані у процесі переробки на виноматеріали. У 2014 р. частка виноматеріалу, що переробляється, суттєво зменши- лась до 52,3\%, а обсяги виробництва скоротилися майже вдвічі - до 6062 тис. дал.

Динаміка виробництва виноградного вина в окремих областях України наведена в табл. 2.

Таблиця 2

Динаміка виробництва виноградного вина в окремих областях України, тис. дал. [4]

\begin{tabular}{|l|c|c|c|}
\hline \multicolumn{1}{|c|}{ Показник } & 2012 & 2013 & $2014^{*}$ \\
\hline Всього виноградного вина по Україні & 12511 & 11603 & 6062 \\
\hline АР Крим & 4197 & 4267 & - \\
\hline Закарпатська область & 1046 & 848 & 895 \\
\hline Одеська область & 2396 & 2270 & 2230 \\
\hline Херсонська область & 295 & 256 & 781 \\
\hline
\end{tabular}

\section{4* - без урахування АР Крим}

Як наголошує Державна служба статистики загальні обсяги переробки винограду на виноматеріали усіма підприємствами України (не враховуючи окуповану територію АР Крим та м. Севастополь) склали у 2014p. 228,933 млн. т, що на 25,7\% менше, ніж у 2013 році. При цьому у поточному році також слід очікувати зменшення обсягів до попереднього року. Якщо порівняти 32013 р., виноробна галузь зменшила свої прибутки майже у 3,3 рази [4]. Стан виноробної галузі в Україні, за основними показниками, наведена в таблиці 3.

Таблиця 3

Стан галузі виноградарства України в період 2011-2014 pp. [4]

\begin{tabular}{|l|c|c|c|c|}
\hline \multicolumn{1}{|c|}{ Показник } & 2011 & 2012 & 2013 & $2014^{*}$ \\
\hline $\begin{array}{l}\text { Валовий збір винограду (усі катего- } \\
\text { рії господарств), тис. т }\end{array}$ & 521,9 & 456,0 & 575,4 & 435,5 \\
\hline Імпорт столового винограду, тис. т & 58,8 & 63,1 & 54,0 & 39,3 \\
\hline Експорт столового винограду, тис. т & 0,09 & 0,06 & 0,14 & 0,06 \\
\hline
\end{tabular}

2014* - без урахування АР Крим

Найбільшою загрозою для виноградарської галузі в Україні є проблеми економічного характеру, які визначають ситуацію в державі та підривають здатність галузі давати достойну відсіч проблемам сьогодення. Насамперед, це стосується очікуваного скорочення обсягів валового збору винограду - за розрахунками фахівців ННЦ «Інституту аграрної економіки» у 2015 р. вони зменшаться більш ніж на $18 \%$ - до 356 тис. т. Близько половини виноробної продукції в Україні має іноземне походження, це пов'язане 3 тим, що пропозиції винограду, який вирощують не перевищує попит. Незважаючи на те, що імпорт столового винограду досить високий, забезпеченість населення столовим виноградом сягає рівня 2,4 кг, у той час, коли за даними МОО3, фізіологічна норма складає 8-10 кг [7]. Великий попит виноробної продукції на внутрішньому ринку відкриває великі можливості та розкриває перспективи для розвитку іiі культури в Україні. Сприятливі кліматичні та грунтові умови дозволяють вирощувати столовий виноград не лише для задоволення внутрішнього ринку, але й для експорту, особливо в північні країни європейського союзу. Географія експорту виноградного вина в Україні наведена в табл. 4.

Таблиця 4

Географія експорту вина виноградного в Україні, тис. т. [4]

\begin{tabular}{|c|c|c|c|c|}
\hline Країна & 2011 & 2012 & 2013 & 2014 \\
\hline Російська Федерація & 31,4 & 44,7 & 62,7 & 39,8 \\
\hline Грузія & 3,1 & 1,7 & 3,2 & 4,5 \\
\hline Країни СС & 2,6 & 2,3 & 2,1 & 1,5 \\
\hline в тому числі і Німеччина & 2,3 & 2,0 & 1,7 & 1,2 \\
\hline Усього & 40,4 & 50,7 & 70,1 & 47,2 \\
\hline
\end{tabular}

Негативний вплив має скорочення обсягів експорту продукції виноробства у Російську Федерацію внаслідок воєнного конфлікту та напружених відносин між державами. Ринок Російської Федерації у 2013 році споживав 89,4\% всього експорту виноградного вина з України, а у 2014 р. ці об'єми скороти- лись до 84,3 \%, такі втрати є досить серйозним викликом для української галузі виноградарства.

Україна має набагато більше можливостей для збільшення експорту виноградного вина. Натомість, експорт українського вина до Європейського Союзу в останні роки досягли $6,5 \%$ від загального 
експорту (2011p.), а у 2014p. вже були на рівні 3,1\%. У 2011-2014 pр. Україна щорічно поставляє 30-43 т вермуту та іншого виноградного вина, з додаванням різноманітних рослинних та ароматичних екстрактів. В той же час китайське виробництво на цьому ринку зросло з 3,3\% у 2013 р. до 27,2\% у 2014 р., а за обсягами - 3 18,8 до 108,4 т [4]. Географія імпорту виноградного вина в Україні суттєво відрізняється від географії експорту (табл. 5).

Географія імпорту вина виноградного в Украӥні, тис. т [4]

\begin{tabular}{|c|c|c|c|c|}
\hline Країна & 2011 & 2012 & 2013 & 2014 \\
\hline Молдова & 30,0 & 13,8 & 11,9 & 7,9 \\
\hline Грузія & 12,6 & 15,2 & 16,7 & 10,6 \\
\hline Країни СС & 11,0 & 13,4 & 16,7 & 16,1 \\
\hline в тому числі Франція & 3,4 & 3,9 & 4,5 & 4,2 \\
\hline Італія & 4,9 & 6,1 & 7,8 & 7,1 \\
\hline Іспанія & 1,6 & 2,1 & 2,5 & 3,3 \\
\hline Усього & 63,1 & 48,0 & 50,8 & 40,1 \\
\hline
\end{tabular}

Скорочення імпорту виноградного вина до України (з 70,1 тис. т у 2013 р. до 47,2 тис. т у 2014 р.) дає поштовх та змогу для вітчизняних виробників реалізувати їх власну продукцію, таким чином даючи вітчизняним виробникам шанс замістити втрачені обсяги поставок до Російської Федерації (в 1,6 рази проти 2013 року). Про розвиток таких можливостей свідчать здобутки виноробів Херсонської області, які у 2014 році збільшили обсяги виробництва більше ніж у 2,6 рази, не зважаючи на те, що виробництво винограду на Херсонщині у 2014 р. проти 2013 р. скоротилося на $14 \%$ [4].

Головною проблемою $з$ якою сьогодні стикається виноробна та виноградарська галузі України це недостатня підтримки з боку держави, а інколи і їі відсутність взагалі. Незважаючи на втрати Україною кримських потужностей, які були найбільшими виробниками вітчизняного вина в країні, а також вирощували виноград, мали свої виробничі підприємства, торгові марки та забезпечували майже $60 \%$ готової продукції виноробства - Україна досить має можливість забезпечувати себе сировиною, але тільки тоді, коли держава знайде змогу фінансово підтримати сировинну базу. На фоні розгорнутого конфлікту 3 Російською Федерацією, українська виноградарська галузь зазнає великих втрат, які можуть спровокувати занепад як вже існуючих виробничих підприємств, так і самої галузі взагалі. Сьогодні на ринку інформаційних послуг використовується багато специфічних інструментарієв для повноцінного та всебічного аналізу трендів та тенденцій розвитку галузей. Тому передові вчені пропонують впровадження інструментів Data Mining [7].

Висновки та перспективи подальших досліджень. В умовах створення асоціації Україна Свропейський Союз, вітчизняним виноробам та вино- градарям доведеться доводити свою конкурентоспроможність на світовому ринку. Боротьба за значиме місце на рівні світового ринку дуже потужна. Для того щоб увійти на світовий ринок зі своєю продукцією українським представникам виноградарської галузі потрібні не лише нові технології та просування вітчизняної продукції на ринок, але й нові високопродуктивні сорти винограду, підвищення та зростання якості продукції, освоєння інноваційних технологій та багато іншого, без чого конкурувати на сучасному ринку виноробної продукції просто не можливо.

Але створення між Україною та Європейським Союзом зони вільної торгівлі може стати для вітчизняних виробників поштовхом та стимулом не тільки для збільшення пропозицій, але й для удосконалення якості продукції.

Проведений аналіз динаміки виробництва виноградного вина в окремих областях України та стану галузі свідчить, що виноградарство займає невелику частку при виробництві валової продукції сільського господарства України. Воно значно знизило свої позиції, як на внутрішньому ринку, так і на зарубіжному. Зараз вітчизняна виноробна галузь переживає важкі часи, іiі розвиток більшою мірою залежить від економічних, політичних подій, а також підтримки державою галузі.

Не зважаючи на всі труднощі у українських виноградарів та виноробів є значний потенціал, досить великий досвід, сприятливі умови та бажання вдосконалюватись, і якщо умови державної політики українського виноробства i виноградарства будуть сприяти щодо розвитку галузі - Україна має всі шанси бути конкурентоспроможною та мати успіх на світовому ринку.

\section{Література}

1. OIV (International Organisation of Vine and Wine). - 2015p. [Електронний ресурс]. - Режим доступу : http://www.oiv.int/oiv/cms/index

2. Баланси сільськогосподарської продукції та продовольства в Україні за 2011-2015pр. / Ю.О. Лупенко, О.М. Шпичак, О.В. Бондар та ін. - К: ННЦ IAE, 2015p. - 50c. 
3. Лупенко Ю.О. Сучасні тенденції розвитку ринку продукції виноградарства в Україні [Електронний peсурс] / Ю.О. Лупенко. - Режим доступу : http://wineofukraine.com/index.php/455-market-trends-2015.html

4. Державний комітет статистики. - 2015p. [Електронний ресурс]. - Режим доступу : http://www.ukrstat.gov.ua/

5. Витрати та ефективність виробництва продукції в сільськогосподарських підприємствах (моніторинг) / О.М. Шпичак, Ю.П. Воскобійник, О.В. Боднар та ін. - К.: ННЦ ІАЕ, 2014 - 452 с.

6. Мулюкіна Н. А. Куди рухається українське виноградарство [Електронний ресурс] / Н. А. Мулюкіна. - Режим доступу: http://wineofukraine.com/index.php/451-movement-ukrainian-viticulture.html

7. Ольшевська О.В. Імплементація сучасного інструментарію аналіза данних для оброблення показників отриманих у системах кондиціювання повітря та холодильних установках / О.В. Ольшевська, А.В. Селіванова // Холодильна техніка та технологія. - 2016. - №51(6). - doi: 10.15673/0453-8307.6/2015.39290

8. Історія виноградарства. [Електронний ресурс]. - Режим доступу : http://vinograd.info/info/grozdyazdorovya/istoriya-vinogradarstva.html

9. Стан виноробної галузі у світі. [Електронний ресурс]. - Режим доступу : http://takeprofit.org/economicnews.php

10. Гаркуша О.М. Проблеми розвитку виноградарсько-виноробного підкомплексу України / О. Гаркуша // Економіка АПК. - 2008. - № 11. - С.3-5.

\author{
Каламан О.Б. \\ кандидат экономических наук, доцент \\ кафедра менеджмента и логистики \\ E-mail: buxgalter11@ukr.net \\ Молчановская А.C. \\ магистрант \\ кафредра безопасности, экспертизы и товароведения \\ E-mail: anastasiia molchanovska@mail.ru \\ Одесская национальная академия пищевых технологий \\ ул. Канатная, 112, г. Одеса, Украина, 65039 \\ E-mail: anastasiia_molchanovska@mail.ru
}

\title{
ТЕНДЕНЦИИ РАЗВИТИЯ МИРОВОГО И УКРАИНСКОГО РЫНКА ПРОДУКЦИИ ВИНОДЕЛИЯ В СОВРЕМЕННЫХ УСЛОВИЯХ
}

В статье описаны современные проблемы и тенденции мирового и украинского рынков продукции виноделия. Показаны изменения площадей виноградников в мире и Украине в частности. Указано, что изменения площадей виноградных насаждений приводят к соответствующему изменению валового сбора. Следующим важным результативным показателем является выпуск винодельческой продукции, который напрямую зависит от проблем отрасли.

Выделены и проанализированы новые лидеры мировой винодельческой отрасли. Указано, что их выход на рынок заставляет отрасль подчиняться новым стандартам и быстрее совершенствовать процесс производства и качество продукции. Изображено состояние развития виноградарства в Украине и описаны его проблемы в современных нестабильных условиях.

Приведены данные по сокращению количества винодельческих предприятий из-за современных политических событий, центром которых является Украина. Поэтому украинская винодельческая отрасль подвергается большому риску не только на мировом, но и на внутреннем рынке.

Проанализирована динамика производства виноградного вина по областям. Приведены основные показатели состояния винодельческой отрасли Украины. Сокращение площадей виноградников, уменьшение валового сбора винограда, нестабильность со стороны государства - все эти фракторы прямым образом влияют на общее состояние винодельческой отрасли Украины. Проблемы требуют постоянного мониторинга, для анализа и поиска их оптимальных решений.

Авторами приведены данные по экспорту и импорту виноградного вина. Было доказано, что украинские производители вина имеют достаточные конкурентные преимущества на этом рынке против иностранных производителей.

Выявлены слабые стороны отечественного производства винопродукции и предложены пути повышения потенциала украинской винодельческой отрасли. Указаны актуальные и острые проблемы и угрозы винодельческой отрасли Украины. Для Украины предложены прогрессивные пути улучшения ситуации в винодельческой отрасли и целесообразные направления ее развития, с учетом ее стратегической перспективы.

Ключевые слова: виноградарство, виноделие, отрасль, рынок, производство, развитие. 


\author{
Kalaman 0. \\ Ph.D. in Economics, Associate Professor \\ Department of Management and Logistics \\ E-mail: buxgalter11@ukr.net \\ Molchanovska A. \\ Undergraduate \\ Department of Safety, expertise and merchandising \\ Odessa National Academy of Food Technologies \\ Kanatna Street, 112 , Odessa, Ukraine, 65039 \\ E-mail: anastasiia_molchanovska@mail.ru
}

\title{
THE DEVELOPMENT TRENDS OF THE WORLD AND UKRAINIAN WINE PRODUCTION MARKET IN MODERN CONDITIONS
}

The article describes the current problems and tendencies of world and Ukrainian winemaking products markets. The changes of the vineyards area in the world and in Ukraine in particular were presented. The changes of the vineyards area lead to the according changes of the gross gathering were indicated. Another important resulting indicator is the wine production output that depends on the problems created in the industry.

Dedicated and analyzed the new leaders of the global wine industry.

Indicated their output to the market forces the industry to comply with new standards as soon as possible and to improve the production process and product quality. Pictured state of viticulture in Ukraine and described its problems in today's unstable conditions.

The dates to reduce the number of winemaking enterprises political events center of which is Ukraine were displayed. Therefore, the Ukrainian wine industry is exposed to greater risk, not only on the world market and on the domestic.

The dynamics of production of grape wine regions were analyzed. The basic indicators of the wine industry in Ukraine were presented. The reduction of the vineyards, reducing the gross gathering, the government instability - are the factors, which have a direct impact on the general state of the wine industry in Ukraine. Problems require constant monitoring for analyze and find their optimal solutions.

The authors presented data on exports and imports of grape wine. It was proved that Ukrainian wine producers have sufficient competitive advantages in this market against foreign manufacturers.

Revealed the weaknesses of domestic production wine products and suggested ways to improve the capacity of Ukrainian wine industry. These actual and acute problems and threats to the wine industry in Ukraine and abroad were described. For Ukraine were offered progressive ways to improve the situation in the wine industry and the most appropriate ways of its development in view of the strategic perspective.

Key words: viticulture, wine, industry, market, production, development.

\section{References}

1. OIV (International Organisation of Vine and Wine). (2015). Retrieved March 2, 2016, from http://www.oiv.int/oiv/cms/index

2. Lupenko, I. O., Shpychak,, O. M., \& Bondar, O. V. (2015). Balansy silskohospodarskoi produktsii ta prodovolstva v Ukraini za 2011-2015rr. K: NNTs IAE.

3. Lupenko, I. O. (2015). Suchasni tendentsii rozvytku rynku produktsii vynohradarstva v Ukraini.

4. Derzhavnyi komitet statystyky. (2015). Retrieved from http://www.ukrstat.gov.ua/

5. Shpychak, O. M., Voskobiinyk, I. P., \& Bodnar, O. V. (2014). Vytraty ta efektyvnist vyrobnytstva produktsii v silskohospodarskykh pidpryiemstvakh (monitorynh). K.: NNTs IAE.

6. Muliukina, N. A. Kudy rukhaietsia ukrainske vynohradarstvo. Retrieved March 3, 2016, from http://wineofukraine.com/index.php/451-movement-ukrainian-viticulture.html

7. Olshevska, O. V., \& Selivanova, A. V. (2016). Implementatsiia suchasnoho instrumentariiu analiza dannykh dlia obroblennia pokaznykiv otrymanykh u systemakh kondytsiiuvannia povitria ta kholodylnykh ustanovkakh. Kholodylna Tekhnika Ta Tekhnolohiia, 51(6). - doi: 10.15673/0453-8307.6/2015.39290

8. Istoriia vynohradarstva. Retrieved March 4, 2016, from Rezhym dostupu : http://vinograd.info/info/grozdya-zdorovya/istoriya-vinogradarstva.html

9. Ctan vynorobnoi haluzi u sviti. (n.d.). Retrieved March 3, 2016, from Rezhym dostupu : http://takeprofit.org/economicnews.php

10. Harkusha, O. M. (2008). Problemy rozvytku vynohradarsko-vynorobnoho pidkompleksu Ukrainy. Ekonomika APK, 11, 3-5. 